\title{
Computing and Engineering Scholarship Program at SCSU
}

\section{Dr. Susantha Herath, St. Cloud State University}

Dr. Susantha Herath is a professor and the Chair of the Information Systems (IS) department at St. Cloud State University. He holds a Ph.D. in computer engineering. His current research interests are in risk management, cyber security and information assurance. He has 25 years of college-level teaching experience at graduate and undergraduate levels and 31 years of research experience. He has published over 75 peer-reviewed articles. He has submitted over 45 competitive grant proposals and received over $\$$ 4 million in funding. Susantha is a senior member of the IEEE.

\section{Dr. Rohitha Goonatilake, Texas A\&M International University}

Dr. Rohitha Goonatilake, professor of mathematics, received his Ph.D. in Applied Mathematics from Kent State University, in Kent, OH in Fall 1997, masters in the areas of applied mathematics, mathematics, and actuarial sciences, and a bachelor's in mathematics/science. He joined TAMIU in the Summer of 1999 and has completed 16+ years of service for TAMIU. He and his team were recently awarded a $\$ 1.2$ million NSF award to promote mathematics education in areas of need in Laredo by providing scholarships to juniors and seniors at TAMIU to prepare them to become talented, skillful, and highly qualified teachers to teach immediately after graduation. Dr. Goonatilake was a recipient of the Scholar of the Year Award in 2006 and the University Honors Faculty of the Year in 2013. He was a PI for more than three program-funded grants and Co-PI for more than 15 different program grants since joining TAMIU. He has a very active research agenda that involves network anomaly detection, probability, disease prevalence, and microeconomics. He was extensively involved with many STEM activities throughout the years for local high school and middle school students, outreach efforts with local high schools, and other community involvements for many years through enrichment workshops and summer opportunities for the local community.

\section{Dr. Suvineetha Herath}




\title{
Computing and Engineering Scholarship Program at SCSU
}

\begin{abstract}
Saint Cloud State University (SCSU) received a US National Science Foundation grant to provide scholarships for academically talented but economically disadvantaged students in information systems, computer science, and computer engineering under SCSU-STEM project. Thirty-six scholarships of up to \$18,200 were awarded during 2011-2016. Twenty-six scholars completed summer internships. The retention rate of scholars was $100 \%$. This project helped to increase undergraduate enrollment, improve retention and graduation, expand active participation in conferences, workshops and summer internships by scholars, and built new structures and strengthen relationships with other 2-year and 4-year colleges, industry and national labs. Marketing materials emphasized the promise of computing in the real world, steady job growth expected for next ten years, and a comparison of lifetime earnings of workers with STEM and other majors.
\end{abstract}

\section{Introduction}

The world needs high-quality, trained majors in Science, Technology, Engineering and Mathematics (STEM) with the ability to learn in a short period and stay current with advances in their respective fields without accumulating massive debts to complete a degree. According to the Bureau of Labor Statistics' in the US [1], job opportunities due to growth and replacements are high in the computing areas compared to biological sciences and physical sciences.

Minnesota has a large number of academically-talented and financially-needy students. In 2008, only 6.9\% of bachelor's degrees awarded in Minnesota were in STEM according to the Minnesota Office of Higher Education. The financial burden is a significant obstacle for students confronting a challenging curriculum that needs more time commitment.

Saint Cloud State University (SCSU) is the second largest in the system of public Minnesota State Colleges and Universities (MN State). SCSU's mission is to prepare students for life, work and citizenship in the twenty-first century to positively transform students and the communities through the discovery, applied knowledge, and creative interaction. It emphasizes fostering scholarship and enhancing collaborative relationships in a global community. SCSU offers nationally accredited high-quality programs. It has seven colleges, over 200 undergraduate and 60 graduate programs, excellent student support structures, and a large number of dedicated faculty members and a large pool of talented graduate assistants. Many of the first generation students come from low-income families. Exceptionally gifted students who chose low-cost two-year community, tribal and technical colleges want to transfer to SCSU to continue their studies. Without an attractive economic package, a college degree is not an option for them.

The total enrollment of 18,319 at SCSU in fall 2010, up 3.6 percent from the year before, comprises diverse populations. SCSU retention rate is 73\%; graduation rate is $46 \%$; female enrollment is 52\%; minority enrollment is $9 \%$. The majority of SCSU students work while going 
to college. The average estimated cost for attending SCSU in 2011-2012 was $\$ 19,812$. About $83 \%$ of enrolled undergraduates received federal aid in 2008. The average amount of financial aid awarded in three computing disciplines in 2010 was ranging from \$ 10,854 to 13,297. Within MN State system, there were 745 graduates from 24 two-year colleges with intended majors in computing, engineering and information systems in 2010.

SCSU-STEM received \$600,000 from the US National Science Foundation, \$290,714 from SCSU to offer 30 biennial scholarships of $\$ 9,100$ per year for four years to students interested in STEM careers at SCSU especially in Information Systems, Computer Science, and Computer Engineering. SCSU-STEM enhanced the ability of underrepresented, academically talented and financially needy students to complete high-quality computing or engineering degree program and aimed at strengthening the STEM workforce and its leadership. It provided a significant change in the award recipient lives, retain in their disciplines and graduate on time. The SCSUSTEM scholars were recruited at the junior level including transfer students. Full-time faculty mentors provided academic advising. Scholars participated in research and senior design projects with peer and graduate assistant support. They also completed internships, attended workshops and conferences to achieve academic excellence. SCSU's current and proposed enhancement to infrastructure assured their success. This award attracted potential applicants and provided sufficient funding to make it possible for financially-disadvantaged students to continue their studies in STEM programs allocating more time to study and eliminating the need to work while studying.

\section{Project Objectives}

The goals of this project, SCSU-STEM, were to (A) Increase the capacity of high-demand STEM areas via recruitment, retention, and graduation of financially-needy, talented students including underrepresented groups, and (B) Strengthen student support structures and interdisciplinary collaborations, enhance faculty and peer mentoring, develop a multidisciplinary research group with exceptional advising, mentor, and tutor, as well as provide directions and skills for a successful life after graduation, either in graduate schools or professional work. These goals match the NSF S-STEM program goals of (1) Improve Educational Opportunities for Students, (2) Increase Retention of Students to Degree Achievement, (3) Improved Student Support Programs at Institutions of Higher Education and (4) Increase the number of well-educated and skilled employees in technical areas of national need.

The project objectives were to (a) Recruit, select and award scholarships for academically talented and financially needy students starting fall 2012. Preference was given to women, students of color and American Indians, first-generation college students, and transfer students from community colleges, (b) Create learning communities for the scholars, (c) Provide summer internships for scholars, (d) Graduate scholars in four years, (e) Gain employment within a year after graduation in high-tech companies or enroll in a graduate program, (f) Increase the number of students and professionals in STEM areas, (g) Promote and enhance relationships among STEM faculty in two-year and four-year colleges, and (h) Improve infrastructure for advising and mentoring. Table 1 depicts the relationship between S-STEM goals and SCSU-STEM objectives. 
Table 1: S-STEM goals and SCSU-STEM objectives

\begin{tabular}{|c|l|l|l|l|}
\hline & S-STEM Goal 1 & S-STEM Goal 2 & S-STEM Goal 3 & S-STEM Goal 4 \\
\hline $\begin{array}{c}\text { SCSU-STEM } \\
\text { Objectives }\end{array}$ & a, g, h & b, c, d & b, h & a, b, e, f \\
\hline
\end{tabular}

The expected outcomes of SCSU-STEM are outlined below:

1. Award thirty, \$9100 per year scholarships for two years in three disciplines during 20122015

2. Achieve at least $90 \%$ of SCSU-STEM participation in seminars and conferences

3. Provide an opportunity for scholars to complete a research/senior design project with a faculty mentor and a presentation at a local seminar/conference

4. Achieve at least $90 \%$ scholar participation in an internship program with industry or national lab

5. Achieve at least a $90 \%$ graduation rate of the SCSU-STEM

6. Achieve $100 \%$ employment or admission into graduate degree programs

7. Achieve at least a $90 \%$ acceptance of scholars who seek admission to graduate degree programs

8. Achieve at least $90 \%$ retention rate for SCSU-STEM

9. Build relationships and establish networking with at least ten two-year colleges

10. Invite high school and 2-year college students to SCSU STEM labs

11. Increase the total enrollment by at least 15\% in 3 STEM disciplines

12. Increase the total enrollment of women, students of color and American Indians, firstgeneration college students and transfer students from community colleges by at least $15 \%$ in 3 STEM disciplines

\section{Project highlights}

SCSU-STEM program offered 36 two-year scholarships to junior level students in information systems, computer science and computer engineering majors during the 2012-2016 period in three cohorts. The scholarships were distributed among the disciplines based on enrollments. Identifying deficiencies before entering the program, monitoring scholars' academic work after joining the program, helping them to succeed and retaining them through degree completion were critical areas of consideration. Outstanding activities of the project included mentoring, 1credit seminar, research, senior design, summer internships, tutoring, field trips and conference participation.

\section{Mentoring}

Each scholar was assigned a faculty mentor, a graduate assistant, and senior undergraduate student peers in his/her major. The faculty mentor prepared a study plan with the scholar and met the scholar bi-weekly. During these meetings, students were advised on topics related to individual progress, research opportunities, internships, successful professional careers and graduate schools. Faculty mentors encouraged scholars to work with faculty to prepare for advanced graduate studies and careers. Graduate and senior student peers provided strong peer to peer networking. Senior scholars served as mentors for junior scholars. 


\section{1-credit seminar course}

All scholars took a 1-credit seminar course during their junior year. In this seminar course, students were taught professional skills, team-building, networking, time management skills, strategies to improve their study habits and classroom performance. Several professional speakers delivered talks on different topics and shared their life and professional experiences to motivate students.

\section{Research}

All scholars were engaged in research or senior design project mentored by the faculty for two consecutive semesters, wrote a report and presented the results at a dedicated seminar, at the annual SCSU Student Research Colloquium or a regional research symposium. Topics of research included cyber security, mobile computing applications, high-performance computing, e-voting, forensics, big data analysis, artificial intelligence and machine learning, software security and engineering, and financial engineering. The scholars were introduced to research teams solving real-life problems. These research projects were designed to improve research skills, problem-solving skills, analytical skills, reading, writing and critical thinking. Scholars were exposed to emerging areas and current research activity, experts, and resources. Faculty supported scholars via introducing them to new approaches, including hands-on skills and teamwork experiences. Providing multidisciplinary technical experience with recent advances in selected areas for scholars to strengthen collaborations among disciplines and improve educational opportunities.

\section{Summer Internship}

An internship coordinator assisted scholars in finding internships and monitoring their progress. These internships provided scholars with a practical experience that enhanced their academic learning and leads to future employment after graduation.

\section{Tutoring}

In addition to the university tutoring system, STEM scholars had a dedicated tutoring system conducted by a graduate student and supervised by a faculty member. Tutoring improved scholars' performance. The management team maintained eight to 16-hour tutoring support per week, based on the scholar needs.

\section{Field Trips}

Once a year, scholars visited a local industry.

\section{Conference Participation}

Scholars actively participated in at least one conference related to their research interest annually. 


\section{Learning Communities}

Scholars formed a natural student cohort during their scholarship period. They were encouraged to take classes together as shown in Table 2.

Table 2: Common courses recommended for scholars

\begin{tabular}{|l|l|l|}
\hline Course \# & Title & Semester \\
\hline Math 273 & Discrete Mathematics & 3 \\
\hline ECE 321 & Microcontrollers & 3 \\
\hline CSCI 301 & Computer Science II & 4 \\
\hline CSCI 310 & Operating Systems & 5 \\
\hline IS 451 & Telecommunications and Networks & 5 \\
\hline IS 443 & Data Modeling with Database Implementation & 6 \\
\hline
\end{tabular}

The scholarship recipients maintained at least a 3.00 GPA at the end of each semester. The management team monitored scholars' GPA every semester to provide feedback to improve their performance continuously. The data provided by the Records and Registration Office and Institutional Data Service on academic performance were used to evaluate and assess scholar's success that lead to continuous improvement, encouraged broad discussion and understanding priorities. During the semester, those who had difficulties in maintaining the required minimum GPA were identified and provided individual guidance and support. Those who failed to meet the minimum GPA requirement at the end of a semester were placed on probation for one semester and were advised to meet their faculty mentors weekly.

\section{Project Management Plan}

AACSB accredited Information Systems department, the first computational science program established at SCSU, has 11 full-time faculty members, all with terminal degrees. Their initiative and contributions helped to establish SCSU as a National Center of Academic Excellence in Information Assurance Education, with National Security Agency and Department of Homeland Security accreditation. Faculty research interests include high-performance graphics processing, cybersecurity, and databases. Numerous computer science graduate students complete their research projects and masters theses in the Business Computer Research Laboratory. The department had close to twenty-five graduate students. The department had smart classrooms and dedicated undergraduate instructional laboratories for computer forensics, parallel computing, operating systems security, database security and network security.

The Computer Science Department has ABET accreditation. The department has 12 full-time graduate faculty members, all with terminal degrees, and 16 teaching assistants. Their research interests range from evolutionary computation, high-performance computing, distributed computing, wireless networks, network security and cryptography to graph theory and software engineering. The department had close to fifty graduate students. Also, it had smart classrooms and dedicated undergraduate instructional laboratories for computer architecture, operating systems, programming languages, networking, database, and systems. 
The Electrical and Computer Engineering Department has ABET accreditation. The department consists of 9 full-time faculty members with research interests ranging from integrated circuit design, robotics, digital signal processing to control systems and graduate teaching assistants. The department has smart classrooms and dedicated undergraduate and graduate instructional laboratories for robotics, signal processing, and digital systems.

The management team included six faculty, two-staff, and several graduate assistants. The PI, Co-PIs and Senior Personnel served as mentors to the STEM scholars. They focused on improving the recruiting, retention and graduation of students in STEM areas for many years. Such efforts have shaped SCSU graduate research and laid the foundation for developing undergraduate research infrastructure in STEM areas. The faculty in the management team had an average of twenty years of experience in research, undergraduate project supervision, graduate theses supervision, and developing and teaching STEM courses. They had organized and participated in workshops and created a network of expertise with other institutions to lay the groundwork for the establishment of the NSA Center of Excellence in Information Assurance.

The following lists show the timeline and activities of SCSU-STEM:

\section{Timeline and Activities - Cohorts 1, 2, and 3}

\section{Year 1}

\section{i. $\quad$ Recruiting}

a. Advertising using University website, flyers, posters, class visits during summer/fall/spring

b. Application deadline - Oct 1

\section{ii. Selection}

a. Evaluation of applications by the management team - By October 20

b. Notify scholarship recipients of scholarship conditions and other information By October 30

c. Award ceremony - By November 15

d. Assign faculty and graduate mentors - By November 30

iii. Retain
a. Orientation and get together - by November 30
b. Form learning communities - by November 30
c. Training for faculty and graduate mentors - by November 30
d. Scholars meet mentors and create an academic plan - by November 30
e. Monthly meeting of scholars and mentors - fall/spring
f. 1-Credit Seminar - Spring
g. Research topic assignment - spring
h. Field trip - spring
i. Attend university colloquium - spring
j. Attend cybersecurity symposium - spring
k. Internship information session - fall
l. Internship - summer 
iv. Evaluate

a. Scholar's first-semester academic progress - beginning of spring

b. Evaluate recruitment and selection process - end of spring

c. Scholars evaluate mentoring service and effectiveness of support structure - end of spring

v. Report

a. Provide data to NSF

\section{Year 2}

i. Retain
a. Internship experience presentation - fall
b. Career fair - fall
c. Graduate school guidance - fall
d. Monthly meeting scholars and mentors - fall/spring
e. 1-Credit Seminar - Spring
f. Research meetings and activities - fall/spring
g. Field trip - spring
h. Attend university colloquium - spring
i. Attend cybersecurity symposium - spring
j. Workshop on resume writing - spring
k. Career fair - spring

ii. Evaluate

a. Scholar's second-semester academic progress - the beginning of fall

b. Scholar's third-semester academic progress - the beginning of spring

c. Evaluate recruitment and selection process - end of spring

d. Scholars evaluate mentoring service and effectiveness of support structure - end of spring

\section{iii. Report}
a. Provide data to NSF
b. Present results at the University Colloquium - spring
c. Publish results in an appropriate computer education conference - end of fall

\section{Advertising and recruitment}

A brochure was developed with the SCSU-STEM application form and emailed to all declared STEM majors. The availability of scholarships was posted on the SCSU homepage, and a description was posted on the SCSU Office of Student Services and in each department. SCSU admission counselors were aware of the availability of these scholarships. The underrepresented students were outreached through the SCSU Multicultural Studies office and American Indian Center, and student organizations. Scholarship availability was communicated with the IEEE/ACM Women student chapter, distributed the scholarship brochure to all 2-year and fouryear colleges in Minnesota, encouraged faculty members in each STEM department to announce the availability of this scholarship in their classes. PIs and senior mentors visited regional 2-year 
colleges in MN to recruit students. Additionally, the availability of scholarships was announced using our state-wide network of STEM instructors.

The project was built on faculty expertise and graduate assistant support, on-campus Software Engineering Internships, honors program, Industrial Advisory Council, First Year Experience Program, Math Skills Center, Student Disability Services, Career Services Center, Professional Networks, and Desire to Learn (D2L). The following recruiting tools were used; American Indian Center; Multicultural Student Services; Cyber Infrastructure, Software, Database and Network Security Conference Series; Summer Math, Science and Discovery Program; and Math Contest.

\section{Scholar Selection Process}

The management team recruited and selected scholars based on financial need, academic standing and the likelihood of success. The selection committee included faculty mentors and the PIs. The awardees were citizens of the US, nationals of the US (as defined in section 101(a) of the Immigration and Nationality Act), aliens admitted as refugees under section 207 of the INS, or aliens lawfully admitted to the US. They were declared majors in Information Systems, Computer Engineering, or Computer Science areas with a 2.75 GPA or above in all academic work completed for the two years preceding the application. They had demonstrated the US Department of Education's financial support need definition, submitted a 500-word long essay and three letters of reference from previous teachers addressing their likelihood of success in rigorous academic work.

Applicants were encouraged to submit the Free Application for Federal Student Aid. Preference was given to students from underrepresented groups. Interviewed selected finalists. At the interview, the selection committee assessed their motivation, ability to manage time and resources, communication skills, and intellectual potential.

\section{Assessment/Evaluation Plan}

Each semester, STEM scholars described their goals at the beginning and summarized their achievements and experiences at the end. By contacting course instructors, their classroom performance was monitored twice at the early stages of each semester. Faculty mentors provided an assessment of numerous activities conducted during the semester to the management team. The Office of Records and Registration tracked scholars' academic records. Successful completion of a research/senior design project demonstrated the level of student learning, engagement, and achievement. At monthly management team meetings, each scholar's performance was discussed, and deficiencies were addressed if any.

At the end of each year, data related to scholars academic performance, mentor meetings, completed internships, completed design projects and research, completed the degree, admitted to graduate school or gained employment were collected and assessed. The number of scholarships awarded, retained and graduated were monitored in assessment and evaluation. 
Scholars had been monitored until they entered a graduate school or employed. This data collection and reporting to the NSF to continue as long as necessary.

The long-term evaluation assessed the number of students who took this expertise to industry, as well as an enhancement of the SCSU student-support infrastructure. A context evaluation of the project addressed by activities such as identifying colleges and faculty participants, establishing partnerships and identifying student populations. This program implementation, recruitment, and participant progress were reviewed and regularly assessed by soliciting feedback from participants via questionnaires and interviews.

The overall success of the program measured by increased enrollment in courses, retention, and completion of degree programs. Also, the number of 2-year colleges visited, and the number of students visited laboratories were also tracked.

Table 3 summarizes objectives, formative assessment to evaluate the effectiveness of activities during the project, expected outcomes and summative assessment to find the overall effectiveness of the program at the conclusion of five years.

Table 3 Assessment Matrix

\begin{tabular}{|c|c|c|c|c|}
\hline Objectives & $\begin{array}{l}\text { Formative } \\
\text { Assessment }\end{array}$ & $\begin{array}{l}\text { Measurement } \\
\text { tool }\end{array}$ & Expected Outcome & $\begin{array}{l}\text { Summative } \\
\text { Assessment }\end{array}$ \\
\hline $\begin{array}{l}\text { 1. Recruit, Select } \\
\text { and Award } \\
\text { scholarships } \\
\text { for } \\
\text { academically } \\
\text { talented and } \\
\text { financially } \\
\text { needy students } \\
\text { from Fall } 2012 \text {. } \\
\text { Preference will } \\
\text { be given to } \\
\text { women and } \\
\text { minorities. }\end{array}$ & $\begin{array}{l}\text { Progress of } \\
\text { scholars } \\
\text { towards } \\
\text { graduation }\end{array}$ & $\begin{array}{l}\text { Advisor } \\
\text { reports and } \\
\text { scholar's } \\
\text { academic } \\
\text { report }\end{array}$ & $\begin{array}{l}\text { 1.Award total of } 30 \\
\text { scholarships in four } \\
\text { disciplines in four } \\
\text { years } \\
\text { 2.Increase total } \\
\text { enrollment by at } \\
\text { least } 15 \% \text { in } 3 \\
\text { STEM disciplines } \\
\text { 3. Increase total } \\
\text { enrollment of } \\
\text { women and minority } \\
\text { by at least } 15 \% \text { in } 3 \\
\text { STEM disciplines }\end{array}$ & $\begin{array}{l}\begin{array}{l}\text { Number of } \\
\text { scholarships } \\
\text { awarded }\end{array} \\
\text { Number of } \\
\text { students } \\
\text { enrolled } \\
\text { Total number } \\
\text { of women } \\
\text { and minority } \\
\text { students } \\
\text { enrolled }\end{array}$ \\
\hline $\begin{array}{l}\text { 2. Create learning } \\
\text { communities } \\
\text { for the scholars }\end{array}$ & $\begin{array}{l}\text { Scholar } \\
\text { participation } \\
\text { in common } \\
\text { courses, } \\
\text { research, } \\
\text { senior design } \\
\text { projects, } \\
\text { seminars and } \\
\text { conferences, }\end{array}$ & $\begin{array}{l}\text { Advisor } \\
\text { reports, } \\
\text { Student reports }\end{array}$ & $\begin{array}{l}\text { 1. Achieve at least } \\
90 \% \text { of the scholars } \\
\text { participating in } \\
\text { seminars and } \\
\text { conferences } \\
\text { 2. Completion of a } \\
\text { project with a faculty } \\
\text { mentor and a } \\
\text { presentation in local } \\
\text { seminar/conference. }\end{array}$ & $\begin{array}{l}\text { Number of } \\
\text { scholars who } \\
\text { participated } \\
\text { in these } \\
\text { activities }\end{array}$ \\
\hline
\end{tabular}




\begin{tabular}{|c|c|c|c|c|}
\hline & $\begin{array}{l}\text { and social } \\
\text { activities }\end{array}$ & & & \\
\hline $\begin{array}{l}\text { 3. Provide } \\
\text { summer } \\
\text { internships for } \\
\text { scholars }\end{array}$ & \begin{tabular}{|l} 
Scholar \\
participation \\
in industry- \\
sponsored \\
internships
\end{tabular} & $\begin{array}{l}\text { Industry } \\
\text { reports, } \\
\text { Student reports }\end{array}$ & $\begin{array}{l}\text { Achieve at least } 90 \% \\
\text { of the Scholars } \\
\text { participating in } \\
\text { internship program } \\
\text { with industry }\end{array}$ & $\begin{array}{l}\text { Number of } \\
\text { scholars who } \\
\text { participated } \\
\text { in } \\
\text { internships. }\end{array}$ \\
\hline $\begin{array}{l}\text { 4. Graduate } \\
\text { scholars in four } \\
\text { years. }\end{array}$ & \begin{tabular}{|l|} 
Monitor \\
scholar's \\
progress \\
\end{tabular} & $\begin{array}{l}\text { Academic } \\
\text { records }\end{array}$ & $\begin{array}{l}\text { Achieve } 90 \% \\
\text { graduation rate of } \\
\text { scholars }\end{array}$ & $\begin{array}{l}\text { Number of } \\
\text { scholars who } \\
\text { graduated. }\end{array}$ \\
\hline $\begin{array}{l}\text { 5. Gain } \\
\text { employment } \\
\text { within a year } \\
\text { after } \\
\text { graduation }\end{array}$ & & Student survey & $\begin{array}{l}\text { Achieve } 100 \% \\
\text { employment or } \\
\text { admission into } \\
\text { graduate degree } \\
\text { programs }\end{array}$ & $\begin{array}{l}\text { Number of } \\
\text { scholars who } \\
\text { joined } \\
\text { industry or } \\
\text { grad school } \\
\text { after } \\
\text { graduation. }\end{array}$ \\
\hline $\begin{array}{l}\text { Enroll in a } \\
\text { graduate } \\
\text { program }\end{array}$ & & Student survey & $\begin{array}{l}\text { Achieve at least } 90 \% \\
\text { acceptance of those } \\
\text { applying for } \\
\text { admission into } \\
\text { graduate degree } \\
\text { programs }\end{array}$ & $\begin{array}{l}\text { Number of } \\
\text { scholars } \\
\text { joined } \\
\text { graduate } \\
\text { school after } \\
\text { graduation }\end{array}$ \\
\hline $\begin{array}{l}\text { 6. Increase the } \\
\text { number of } \\
\text { students in } \\
\text { STEM areas }\end{array}$ & $\begin{array}{l}\text { Monitor } \\
\text { enrollment } \\
\text { data }\end{array}$ & $\begin{array}{l}\text { Institutional } \\
\text { data }\end{array}$ & $\begin{array}{l}\text { Achieve } 90 \% \\
\text { retention rate for } \\
\text { scholars }\end{array}$ & $\begin{array}{l}\text { Retention } \\
\text { rate }\end{array}$ \\
\hline $\begin{array}{l}\text { 7. Promote and } \\
\text { enhance } \\
\text { relationships } \\
\text { among STEM } \\
\text { faculty in 2- } \\
\text { year and 4-year } \\
\text { colleges. }\end{array}$ & \begin{tabular}{|l} 
Monitor \\
number of \\
school visited
\end{tabular} & Faculty reports & $\begin{array}{l}\text { 1. Build } \\
\text { relationships and } \\
\text { establish networking } \\
\text { with at least } 10 \text { two- } \\
\text { year colleges. } \\
\text { 2. Invite high school } \\
\text { and 2-year college } \\
\text { students to visit } \\
\text { SCSU STEM labs. }\end{array}$ & $\begin{array}{l}\text { Number of } \\
\text { relationships } \\
\text { built. } \\
\text { Number of } \\
\text { students who } \\
\text { visited labs } \\
\text { at SCSU }\end{array}$ \\
\hline $\begin{array}{l}\text { 8. Improve } \\
\text { infrastructure } \\
\text { for advising } \\
\text { and mentoring }\end{array}$ & $\begin{array}{l}\text { Increased } \\
\text { enrollment in } \\
3 \text { STEM } \\
\text { disciplines } \\
\text { selected }\end{array}$ & $\begin{array}{l}\text { Enrollment } \\
\text { and retention } \\
\text { data }\end{array}$ & $\begin{array}{l}\text { 1. Increase total } \\
\text { enrollment by at } \\
\text { least } 15 \% \text { in } 3 \\
\text { STEM disciplines } \\
2 \text {. Increase total } \\
\text { enrollment of } \\
\text { women and minority } \\
\text { by at least } 15 \% \text { in } 3 \\
\text { STEM disciplines }\end{array}$ & $\begin{array}{l}\text { Number of } \\
\text { students who } \\
\text { enrolled in } 3 \\
\text { STEM } \\
\text { disciplines }\end{array}$ \\
\hline
\end{tabular}




\section{Specific project outcomes}

Table 4 illustrates the number of majors for each program for six years. The project helped increasing student interest in Information Systems, Computer Science, and Computer Engineering at SCSU.

Table 4 Enrollment Data

\begin{tabular}{|l|l|l|l|l|l|l|}
\hline Major & $\mathbf{2 0 1 0}$ & $\mathbf{2 0 1 1}$ & $\mathbf{2 0 1 2}$ & $\mathbf{2 0 1 3}$ & $\mathbf{2 0 1 4}$ & $\mathbf{2 0 1 5}$ \\
\hline Computer Engineering & 28 & 40 & 48 & 72 & 87 & 196 \\
\hline Computer Science & 82 & 94 & 126 & 173 & 219 & 566 \\
\hline Information Systems & 64 & 107 & 149 & 190 & 200 & 432 \\
\hline TOTAL & $\mathbf{1 7 4}$ & $\mathbf{2 4 1}$ & $\mathbf{3 2 3}$ & $\mathbf{4 3 5}$ & $\mathbf{5 0 6}$ & $\mathbf{1 1 9 4}$ \\
\hline
\end{tabular}

Table 5 depicts the number of disadvantaged group members in each area for 2011-15 years.

Table 5 Enrollment of disadvantaged group members 2011-2015

\begin{tabular}{|l|l|l|l|l|l|l|l|l|}
\hline & \multicolumn{2}{l}{ CE } & \multicolumn{2}{l}{ CS } & \multicolumn{2}{l|}{ IS } & \multicolumn{2}{l|}{ TOTAL } \\
\hline & $\mathbf{2 0 1 1}$ & $\mathbf{2 0 1 5}$ & $\mathbf{2 0 1 1}$ & $\mathbf{2 0 1 5}$ & $\mathbf{2 0 1 1}$ & $\mathbf{2 0 1 5}$ & $\mathbf{2 0 1 1}$ & $\mathbf{2 0 1 5}$ \\
\hline Female & 0 & 14 & 10 & 93 & 21 & 108 & 31 & 215 \\
\hline Student of Color & 5 & 95 & 40 & 231 & 36 & 201 & 81 & 527 \\
\hline First Generation & 3 & 36 & 6 & 60 & 3 & 94 & 12 & 190 \\
\hline American Indian & 0 & 4 & 0 & 4 & 0 & 5 & 0 & 13 \\
\hline 2-Year Transfer & N/A & 81 & 0 & 206 & 0 & 231 & N/A & 518 \\
\hline
\end{tabular}

Table 6 illustrates the distribution of scholarships among disadvantaged groups.

Table 6 Distribution of Scholarships disadvantaged groups

\begin{tabular}{|l|l|l|l|l|l|l|}
\hline \multirow{2}{*}{} & \multicolumn{2}{|l|}{2012 - Cohort 1 } & \multicolumn{2}{l|}{ 2013-Cohort 2 } & 2014-Cohort 3 \\
\cline { 2 - 7 } & Count & Percent & Count & Percent & Count & Percent \\
\hline Female & 2 & $20 \%$ & 4 & $40 \%$ & 3 & $19 \%$ \\
\hline Student of Color & 2 & $20 \%$ & 4 & $40 \%$ & 3 & $19 \%$ \\
\hline First Generation & 7 & $70 \%$ & 5 & $50 \%$ & 13 & $81 \%$ \\
\hline 2-Year Transfer & 6 & $60 \%$ & 4 & $40 \%$ & 5 & $31 \%$ \\
\hline
\end{tabular}

Cross-advertising along the boundaries of different colleges, schools, and programs were our key to success in a very short period. Steady job growth expected for next decade for those who with computing skills. Workers with computing background get increased lifetime earnings compared to other non-computing majors. 
The scholarship recipients maintained at least a 3.00 GPA at the end of each semester. The management team monitored scholars' GPA every semester to provide feedback to improve their performance continuously. The data provided by the Records and Registration Office and Institutional Data Service on academic performance were used to evaluate and assess scholar's success that lead to continuous improvement, encouraged broad discussion and understanding priorities. During the semester, those who had difficulties in maintaining the required minimum GPA were identified and provided individual guidance and support. Those who failed to meet the minimum GPA requirement at the end of a semester were placed on probation for one semester and were advised to meet their faculty mentors weekly.

Research, seminars, conferences, workshops and teamwork: Each scholar actively engaged in a research project with practical applications, participated in local St. Cloud State Research Colloquium and regional conferences. Scholars were encouraged to continue their research in areas with challenging problems and inspired them to become future professionals. $100 \%$ of scholars from all cohorts completed a project and presented a paper at a conference. The management team invited several excellent researchers from industry, government, and academia to share their experience with scholars. This project brought together a group of faculty from diverse disciplines to initiate the development of a multidisciplinary learning and research community and develop new faculty-student collaborative research projects. The faculty team was available throughout the academic year for consultation.

New connections with industry and national labs: Each year scholars visited at least one industry or a research facility with PIs. With the help of the Industrial Advisory Council, a hightech business outreach effort was made for the benefit of the scholars. This initiative contributed to enhancing our laboratories. These new connections will help to excite and attract more high school or college students to select a career path in the STEM.

Summer Internships in industry and government labs helped our scholars to complete summer internships. Twenty-six scholars finished a summer internship project with an industry or a government agency. $90 \%$ of scholars from cohort 1, 100\% from cohorts 2 and 3 completed a summer internship.

Leadership: Each scholar is given a leadership role in a year-long team project while helping them to be an effective team member in another project to succeed at an early stage in their lives. This project introduced unique leadership building experiences with challenges to scholars. They were also encouraged to complete a MOOCS leadership course. All scholars provided a leadership opportunity to complete a project.

Increased connections with 2-year colleges: PIs held roundtable discussions with STEM program coordinators in community colleges to provide smooth transitioning from 2-year to 4year college degree. The PIs established close relationships with thirteen 2-year colleges. Also, PIs participated in offering summer experiences for high school students from underrepresented groups in residential STEM program.

Increased connections with high schools: The Annual SCSU Pipeline Summer Camps were held for more than 100 underrepresented high school students. The Annual STEM Summits 
were held in 2013, 2014 and 2015 for grades 7-12 students. Our scholars shared their experiences and information related to high demanding STEM careers. Also, a total of $\sim 4,000-$ grade 7-12 students from forty-six schools participated in Math-Contests.

New structures to strengthen STEM workforce: The management team implemented a new 4+1 program to help students complete a Master of Science in Information Assurance. This program is accepting undergraduate students from information systems, computer science, and related disciplines, then shepherding them through their baccalaureate degrees into the Master's degree in Information Assurance and Cybersecurity at SCSU. Students majoring in business or liberal arts disciplines are encouraged to enter into the Information Systems major first and then continue their studies to earn master's degree in Information Assurance and Cybersecurity. Also, the management team implemented a new 15 credit Software Engineering concentration and 120 credit major. Scholar-specific new support structures were built upon the already strong, established institution-wide student support infrastructure.

Mentoring of scholars by experienced faculty, the use of graduate assistants and peers in tutoring, research, seminars and design projects enhanced the scholar's educational experiences. This also improved the undergraduate and graduate research environment and increased both numbers and diversity in long-term career opportunities in the STEM workforce. Improved communications strengthened regional inter-institutional collaborations and the overall quality of education.

By exposing students to positive learning experiences at an early stage in their careers, the management team encouraged more to continue their education in these growing fields and inspired them to become future experts. Scholars received advice from a faculty member with more than fifteen years of classroom teaching and research experience. Seminars strengthened student abilities in reading, writing, and critical thinking and increased their enthusiasm for solving complex real-world problems and finding solutions collaboratively. It helped students broaden their research capacity, increase participation and subsequently augmented the nation's future technical workforce capacity. Consequently, both the public and private sectors benefited from the greater number of highly-skilled trained professionals.

The management team reached out to both local and national academic communities. News releases on NSF participation in assisting STEM students stimulated the community to support NSF aims. The management team maintained a website to publicize the NSF-STEM scholarship program, recruiting and retention efforts, disseminate research results, assessment of student learning, and the names of the scholarship recipients. The IEEE Women in Engineering Chapter is used as a vehicle to encourage women participation in STEM education. Also, to attract more students from underrepresented groups and women to STEM areas, our team organized and participated in annual SCSU-STEM conferences, summer camps and the Math Contest events which brought in many high school students to the campus. Recognition of the scholars took place at an annual banquet and during commencement ceremonies. The management team disseminated results and the names of the scholarship recipients to the supporting student organizations and the President's Council. Annual assessment results were shared with all participants of our annual conference series and the industry advisory council. The management team shared the experience gained from this work with faculty who are interested in developing 
similar programs at SCSU, in other colleges in $\mathrm{MN}$ and surrounding five states through regional conferences. At the national level, the program results will be presented at a conference. The faculty empowered STEM scholars; the scholars empowered their families and took their talents to the workforce.

\section{Future Work}

Based on the lessons learned, the management team would like to propose and attract noncomputing majors to address the national need for cybersecurity professionals and transform their minds and lives. The target pool includes students from non-computing majors, veterans, 2year transfer students from $\mathrm{MN}$ and five neighboring states. The team expects them to share the benefits of healthy job growth projected for next ten years with improved lifetime earnings and transform the historically agriculture-based economy to advanced high technology-based one.

Our experience shows the first generation diverse students can make a significant impact on the economic development. This proposed future work offers a better understanding of skills needed, the importance of collaborating across disciplines and a career in the world after graduation. Many of our first-generation students come from low-income families. Students learn cybersecurity subjects that are more engaging and easy to learn. Exceptionally talented students who chose non-computing majors or low-cost two-year colleges want to transfer to SCSU to continue their studies. Without an attractive economic package, a college degree is not an option for them. The management team plans to expand existing liaisons and develop new connections with other universities and colleges to increase cybersecurity awareness and the number of students interested in cybersecurity. These proposed group of scholars will graduate with the necessary foundation to protecting and defending the cyberinfrastructure and be successful in their careers in government, industry or graduate school. Community leaders and local companies are depending on universities and 2-year colleges to prepare students for the future opportunities and challenges.

\section{Acknowledgment}

This project was supported by the National Science Foundation Grant Award \# 1154398.

\section{References and Bibliography}

[1] 2013 Bureau of Labor Statistics' Employment Projections for 2012-22 [online]. Available: http://www.bls.gov/news.release/pdf/ecopro.pdf.

[2] T. Estes, J. Finocchiaro, J. Blair, J. Robison, J. Dalme, M. Emana, L. Jenkins and E. Sobiesk, "A Capstone Design Project for Teaching Cybersecurity to Non-technical Users," SIGITE 2016.

[3] D. F. Whalen and M.C. Shelley, “Academic Success for STEM and Non-STEM Majors.” Journal of STEM Education, 2010. 
[4] B. W. Packard, J. L. Gagnon and A. Senas, “Avoiding unnecessary delays: Women and men navigating the community college transfer pathway in science, technical, engineering, and mathematics fields." Community College Journal of Research and Practice. 2012.

[5] J. G. Baker and M. G. Finn, "Can a Merit-Based Scholarship Program Increase Science and Engineering Baccalaureates?” [Online]. http://www.eric.ed.gov/PDFS/EJ790178.pdf

[6] N. S. Shapiro, J. H. Levine, and J Levine, Creating Learning Communities: A Practical Guide to Winning Support, Organizing for Change and Implementing Programs: Wiley, 1999

[7] Z. S. Wilson, L. Holmes, K. deGravelles and M. R. Sylvain, "Hierarchical Mentoring: A Transformative Strategy for Improving Diversity and Retention in Undergraduate STEM Disciplines,” Journal of Science Education and Technology, vol. 21, pp 148-156, Feb. 2012

[8] C. M. Engstrom and V. Tinto, "Learning Better Together: The Impact of learning communities on the Persistence of Low-Income Students.” Opportunity Matters, vol. 12008. [Online]. http://www.pellinstitute.org/journal/Pell_OppMattersv1_EngstromTinto.pdf

[9] J. McNeil, C. Kerk and S. Kellogg, "Tiospaye in Engineering and Science: Inculcating a Sustained Culture for Recruiting, Retaining, and Graduating American Indian Students”, in 41st ASEE/IEEE, Frontiers in Education Conference, 2011

[10] L. M. Rocconi, "The Impact of Learning Communities on First Year Students' Growth and Development in College," Research in Higher Education, vol. 52, pp 178-193, 2011 